$\xi=-$ 国

\title{
The Impact of Smartphone Adoption on Marketing Therapeutic Tourist Sites in Jordan
}

\author{
Mahmoud Alghizzawi ${ }^{1}$, Mazuri Abd. Ghani' ${ }^{1}$, Ahmad Puad Mat Som ${ }^{2 *}$, Muhamad Fazil Ahmad², Aziz Amin ${ }^{2}$, Nor- \\ suhaily Abu Bakar ${ }^{2}$, Said A. Salloum ${ }^{3}$, Mohammed Habes ${ }^{4}$ \\ ${ }^{1}$ Faculty of Economics and Management Sciences, Universiti Sultan Zainal Abidin, Gong Badak Campus, 21300 Kuala Nerus, Tereng- \\ ganu, Malaysia \\ ${ }^{2}$ Faculty of Applied Social Sciences, Universiti Sultan Zainal Abidin, Gong Badak Campus, 21300 Kuala Nerus, Terengganu, Malaysia \\ ${ }^{3}$ Faculty of Engineering \& Information Technology, University of Fujairah, Fujairah, United Arab Emirates \\ ${ }^{4}$ Faculty of Engineering \& Information Technology, The British University in Dubai, Dubai International Academic City, Dubai, United \\ Arab Emirates \\ Corresponding author Email: puadms@unisza.edu.my
}

\begin{abstract}
The aim of the study is to find out the effect of smartphone on marketing therapeutic tourist sites in Jordan. Several factors contribute to this study, including market type templates, therapeutic, demographic and their impact on tourist behavior in Jordan. We apply the technology acceptance (TAM) model to study through the incorporation of smartphone applications on marketing therapeutic tourist sites in Jordan. To achieve this, we use the quantitative research design and rely on appropriate data to test the hypothesis. We distributed questionnaire to 400 tourists as a sample of study but two hundred and four were collected. The researchers had used the structural equation modeling (PLS-SEM) for measuring relationships and correlations between variables and their impact on the behavior of tourists in Jordan. According to the study findings, there was a positive impact on market type template, therapeutic, and demographics on tourists' perceived ease of use of smartphone on marketing therapeutic tourist sites in the country. Perceived usefulness and perceived ease of use also led to an increase in tourists' intention to use smartphone.
\end{abstract}

Keywords: Smartphone; therapeutic tourist sites; perceived usefulness; perceived ease of use; market type template; Jordan.

\section{Introduction}

Nowadays, smartphones are considered the axis of the technological revolution in the Internet age. This has gained globalization in a short period of time [1]. The cell phone (especially smartphone) has become the focus of consumer interest in life and business [1]. Smartphones have grown to be as smart as computers. They provide a wide range of information services that can be read anytime anywhere. With the collective number of users and diversity of their thoughts and orientations, smartphones are going to impact on tourist behavior [2]. Jordan came in first globally in terms of usage of internet and smartphones relative to the social media applications, 90\% in 2016 [3]. As far as smartphones are considerd, Facebook and WhatsApp by far are the most used social network channels in Jordan [3]. Today, smartphone users, including tourists, have the talent to conduct transactions and services, access information, and select tourist places [2]. The rapid developments of mobile technology and mobile internet networks have made smartphones more capable of providing services and the purchase of goods (electronic commerce). Smartphones provide smart, diverse applications and easy access to tourist products and therapeutic sites [4]. They also deliver a variety of applications and services for tourists and tourism companies, using various media text, audio, and video, SMS [5]. Tourists are attracted to smartphones for their many practical and entertainment applications. Through the additional features provided by smartphones, a tourist can customize the services he needs through therapeutic tourism applications commensurate with his need [6]. The concept of therapeutic tourism has evolved side by side with the development of technology, and many countries have offered these tourism services through smartphone applications by marketing these services in Asian countries, including Jordan [7]. In addition to the evolution of the concept of health care, is the development of health and health care trade, and travel of patients across borders for treatment. In addition to health, there is a term called medical therapeutic tourism [8]. There are various ways to promote therapeutic tourism including smartphone - "marketing therapeutic tourist sites when patients and tourists plan to travel across borders with a view to obtaining health and therapeutic care [9].

According to [10], using smartphone to promote therapeutic tourist site contributes to enhancing the promotional role of tourist locations and the competitive environment of the tourist and archaeological locations that depend on the technological means and data, which in turn promotes medical tourism, thus increasing the number of tourists to therapeutic countries, including Jordan [7]. Jordan contains many important locations which are valuable for their medical and therapeutic values, which aim to fulfill the new definition of therapeutic tourism and lead the worldwide standards. Jordan enjoys miscellaneous nature, rich in natural resources, such as mineral water and hot waterfalls, volcanic mud, and many medical therapeutic products [11]. Moreover, in Jordan, many medical facilities and specialized hospitals offer highly efficient and specialized services for most patients, with a fabulous reputation all over the globe [7]. Hotels, resorts and restaurants have also aided in the growth of therapeutic tourism by providing many services 
and attractions to tourists in general [12]. The aim of the study is to identify the use of smartphones in the promotion of therapeutic tourism and finds out the effect smartphone on marketing therapeutic tourist sites in Jordan. The research seeks to answer the following questions:

- Identify the use of smartphones on the promotion of therapeutic tourism.

- Examine the most important effects of smartphone which create behavior of tourist.

- Identify the most influential marketing templates of the tourist.

\section{Literature Review}

Smartphone features of the current era is considered one of the new media and the latest marketing methods that provide services for users in various activities including tourist activities [6]. Smartphone provides clearer visions for customers, about tourist information due to the latest smartphone capabilities. Compared with the old phones, smartphones provide information such as speaking skills and text messages, as well location identification and other services needed by the tourists [13].

The technological development of smartphone and the efficiency of the phone are important factors in the selection of appropriate marketing style. With the new smartphones, they enjoy large screens and high-volume storage that add to marketing template. [6]. Today, smartphone users including tourists have the talent to conduct transactions, services, access information and buy goods anytime, make booking and select tourist places [2]. Thus, a smartphone provides a new and innovative feature in marketing, and opens the way for marketers to innovate new ways of delivering service to tourists, unlike the old methods of marketing over the phone which depend on personal communication and direct follow-up [14]. The diversity of marketing methods, via smartphones affect the satisfaction of the recipients, about the provision of goods and services including tourist sites. According to a study [15], the loyalty of users of goods and services and the quality of the visitor base directly affects the expected results of the service or commodity [13].

\section{Research Model and Hypotheses}

\subsection{Marketing Templates by Smart Phones}

The emergence of smartphones made it possible for companies to offer more personalized content, as smartphones are one of the most modern technological means that have the ability to save information and assemble proximally [16]. The internet of things increases those possibilities of easy gathering of more data, which can be marketed over these phones [17]. Marketing via smartphones is the starting point towards marketing for various services and commodities, as well developing an opportunity for marketers to diversify marketing plans and discover new ways. Because of its advantages, not to mention the spread of the internet [18], marketers succeeded in creating new markets for consumers and create job opportunities in the field of tourism, creating new ways of marketing via smartphones [17].

Moreover, the widespread use of mobile devices and the low cost in setting an advertisement on mobile devices have motivated companies to invest in mobile advertisement [19]. Advertising through mobile phones has offered numerous benefits to companies, such as delivering a personalized message to consumer-based preferences and interest [20] via SMS, special applications and social media, where there is a need for consumers and marketers to understand its benefits such as interactivity, costing and personalization [16].

There are few studies [21-24], which are looking at direct marketing techniques via smartphones, and the impact of direct advertis- ing to the public, despite the progress and development of the industry at present [16]. In theory, these phones are very useful to consumers and tourists and be a catalyst in finding the important resources they are looking for, whenever and wherever they are. Also,smartphones offer convenience, the time and effort in practical terms for users [18]. It is also considered the medium of direct advertising to consumers with acceptable method [17]. This behavior demonstrates that mobile phone users have a strong attachment to their mobile phones. Accordingly, this will be a good indication for advertisers to leverage the positive use of mobile phones and to further contribute to companies. Wide-spread adoption of mobile devices has provided marketing opportunities to an expanded set of possibilities to serve consumers despite location and geographic difference [6]. From the above said discussion, the following hypotheses have been suggested: H1: Market type template (MT) has a positive effect on the tourists' perceived usefulness (PU) of the smartphone and H2: Market type template (MT) has a positive effect on the tourists' perceived ease.

\subsection{Therapeutic Tourists}

In recent days, the interest in tourism increased because of the impact of tourism in the development of countries, including therapeutic tourism [24]. The term therapeutic tourism means the movement of people and groups, searching for countries that provide therapeutic services, through the availability of areas for natural therapeutic tourism or medical hospitals, health care centers and relaxation centers, in various countries of the world [10]. Therapeutic tourism, in spite of being relatively new, has experienced a wide growth recently. The good thing about therapeutic tourism is that it provides both bodies and brains healing together [24]. The therapeutic tourism does not rely on mineral water baths and natural therapeutic places, it also depends on clinical as well healthcare development in the nations that provide modern medical care facilities [25]. According to earlier studies, constructs about therapeutic tourists will be the contributing factors of individual objectives [21, 26, 17]. Accordingly, the following hypotheses were tested: H3: Therapeutic (TH) has a positive effect on the tourists' perceived usefulness (PU) of the smartphone and H4: Therapeutic (TH) has a positive effect on the tourists' perceived ease of use (PEOU) of the smartphone (see Fig. 1).

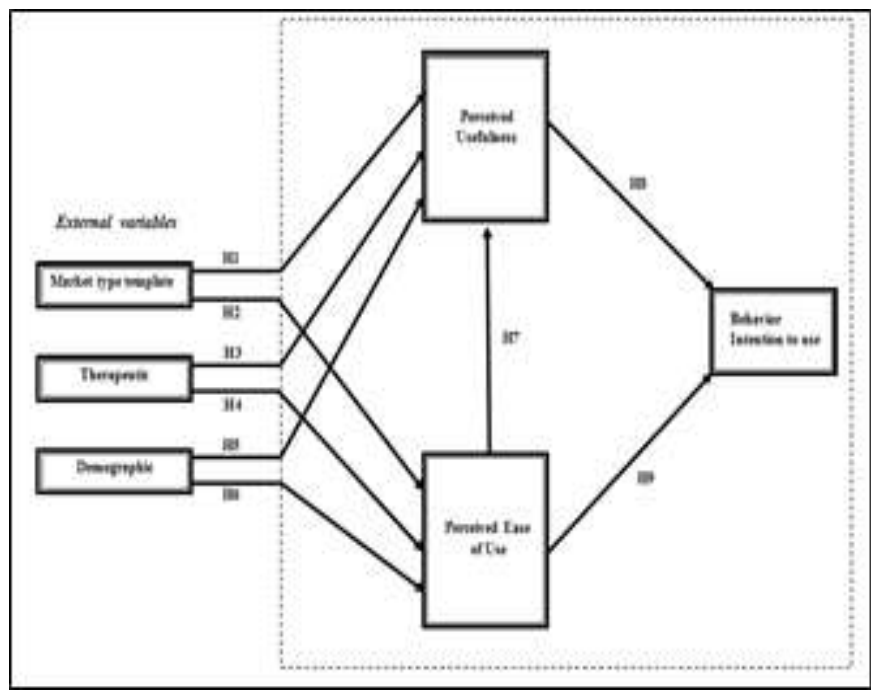

Fig. 1: Hypotheses and External Variables

\subsection{Underlying Theories (TAM Model)}

According to [27], the actual behavior of people has a tendency to act in a certain way, and this intention is affected by their positions and their personal standards (social behavior). This is called TAM model, the technology acceptance model. The following Fig. 2 depicts the technology acceptance model (TAM). 


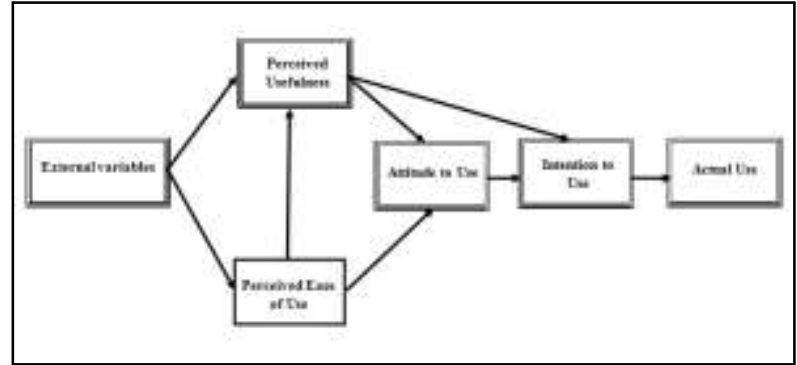

Fig. 2: Technology Acceptance Model (TAM) [27]

The technology acceptance model (TAM) model is based on two factors to determine the intent of user's behavior on perceived ease of use and perceived usefulness to determine the user's intent and connect them with the application or technological means [28] As compared to other models, TAM is believed to be more accurate when predicting the level of acceptance of technology when using smartphones. Therefore, it is considered a perfect model to determine the results for the perceived ease of use and perceived usefulness [29-30]. This study attempts to compare and find the relationships between the dependent variables (intention, market type template, usability, therapeutic, and technology acceptance model) $[27,29,31,32,33,20]$. According to [34], there are perceptions of smartphones' dependence on marketing, so that they are measurable and adapted to TAM constructs, such as acceptance of users' age $[26,31,35,26]$. From the above-said discussion, we have suggested the following hypotheses.

H5: Demographic (DC) has a positive effect on the tourists' perceived usefulness (PU) of the smartphone.

H6: Demographic (DC) has a positive effect on the tourists' perceived ease of use (PEOU) of the smartphone.

H7: Perceived ease of use (PEOU) has a positive effect on the perceived usefulness (PU) of the smartphone.

H8: Perceived usefulness (PU) has a positive effect on the behavioral intention to use (BI) of the smartphone.

H9: Perceived ease of use (PEOU) has a positive effect on the behavioral intention to use (BI) of the Smartphone

\section{Methodology}

\subsection{Target Population and Unit of Analysis (UOA)}

The target population of this research is tourists in therapeutic tourist places in Jordan. In order to investigate the purpose of the study in identifying, whether positively or negatively themed marketing through smartphones have stronger impact on tourists, this study uses a quantitative research design and quantitative data, which are more efficient and able to test the hypotheses. The questionnaire was distributed to 400 tourists by using the survey method, but the total number of questionnaires collected was two hundred four. The structural equation modeling (PLS-SEM) has been used for measuring relationships and correlation between variables and their impacts on the behavior of tourists in Jordan.

\subsection{Instrument}

Identifying the survey method and the process of data collection are essential steps in the survey design. The study's instrument represents the primary data collection technique which is the questionnaire. In this research, items were selected based on previous studies in marketing and smartphones' user behaviors. The researcher will use the Likert scale to measure respondents' opinions. A five-point Likert scale ranging from 'strongly agree' to 'strongly disagree' will be employed as it has been mostly recommended by researchers that it would reduce the frustration level of responses and increase response rate and response quality [36].

\subsection{Demographic Data}

Demographic profile of respondents has been assessed and the results are stated in Table 1 . The female student percentage was recorded at $48 \%$ and the male percentage was $52 \% .38 \%$ of the respondents' age was between 18 and 29 years old. Jordanians made up 65 per cent of total respondents, with the remaining from other countries.

Table 1: Demographic Data

\begin{tabular}{|c|c|c|c|}
\hline Variables & Answers & Frequency & Percentage \% \\
\hline Gender & Female & 98 & $48 \%$ \\
\cline { 2 - 4 } & Male & 106 & $52 \%$ \\
\hline \multirow{4}{*}{ Age } & 18 to 29 & 78 & $38 \%$ \\
\cline { 2 - 4 } & 30 to 39 & 73 & $36 \%$ \\
\cline { 2 - 4 } & 40 to 49 & 29 & $14 \%$ \\
\cline { 2 - 4 } & 50 to 59 & 10 & $5 \%$ \\
\cline { 2 - 4 } & $60+$ & 14 & $7 \%$ \\
\hline Nationality & Jordanian & 132 & $65 \%$ \\
\cline { 2 - 4 } & Arabs & 19 & $9 \%$ \\
\cline { 2 - 4 } & Aruba & 6 & $3 \%$ \\
\cline { 2 - 4 } & East Asia & 3 & $5 \%$ \\
\cline { 2 - 4 } & American & 10 & $17 \%$ \\
\cline { 2 - 4 } & Other & 34 & $1 \%$ \\
\hline
\end{tabular}

\section{Results and Discussion}

Data analysis was carried out by implementing the PLS (partial least square) method. One of structural equation modeling (SEM) methods through which the relationship could be evaluated within model is known as the PLS [37]. Researchers choose the PLS due to its potential to investigate the small sample sizes [38]. Besides having a prediction objective, it could give good performance and the model reveals different phenomena, modified or new [39]. The simple navigation and other salient features have been explored against the smart PLS application. There are two steps in the PLS analysis: the measurement model analysis and structural model analysis [40]. To examine the validity and reliability of the latent variables, the first measurement would execute confirmatory factor analysis (CFA) in the first step [41]. In contrast, by examining path coefficients and their significance, the hypotheses would be tested by the second measurement.

\subsection{Data Analysis}

A confirmatory assessment of reliability, discriminant validity, and convergent validity are given by the analysis of measurement model [42]. Examining the loading factor of model's variables was the first step to measure the model. In this regard, the PLS algorithm function can be executed in Smart PLS, so that the desired results could be achieved. Table 2 illustrates the outcomes of the outer model test.

Table 2: Convergent validity results which assure acceptable values (Factor loading, Cronbach's Alpha, composite reliability $\geq 0.70$ \& AVE $>0.5$ )

\begin{tabular}{|c|c|c|c|c|}
\hline Constructs & Items & $\begin{array}{c}\text { Factor } \\
\text { Loading }\end{array}$ & Cronbach's Alpha & CR \\
\hline Behavior Intention to & ADOPTION_1 & 0.808 & 0.776 & 0.841 \\
\hline
\end{tabular}




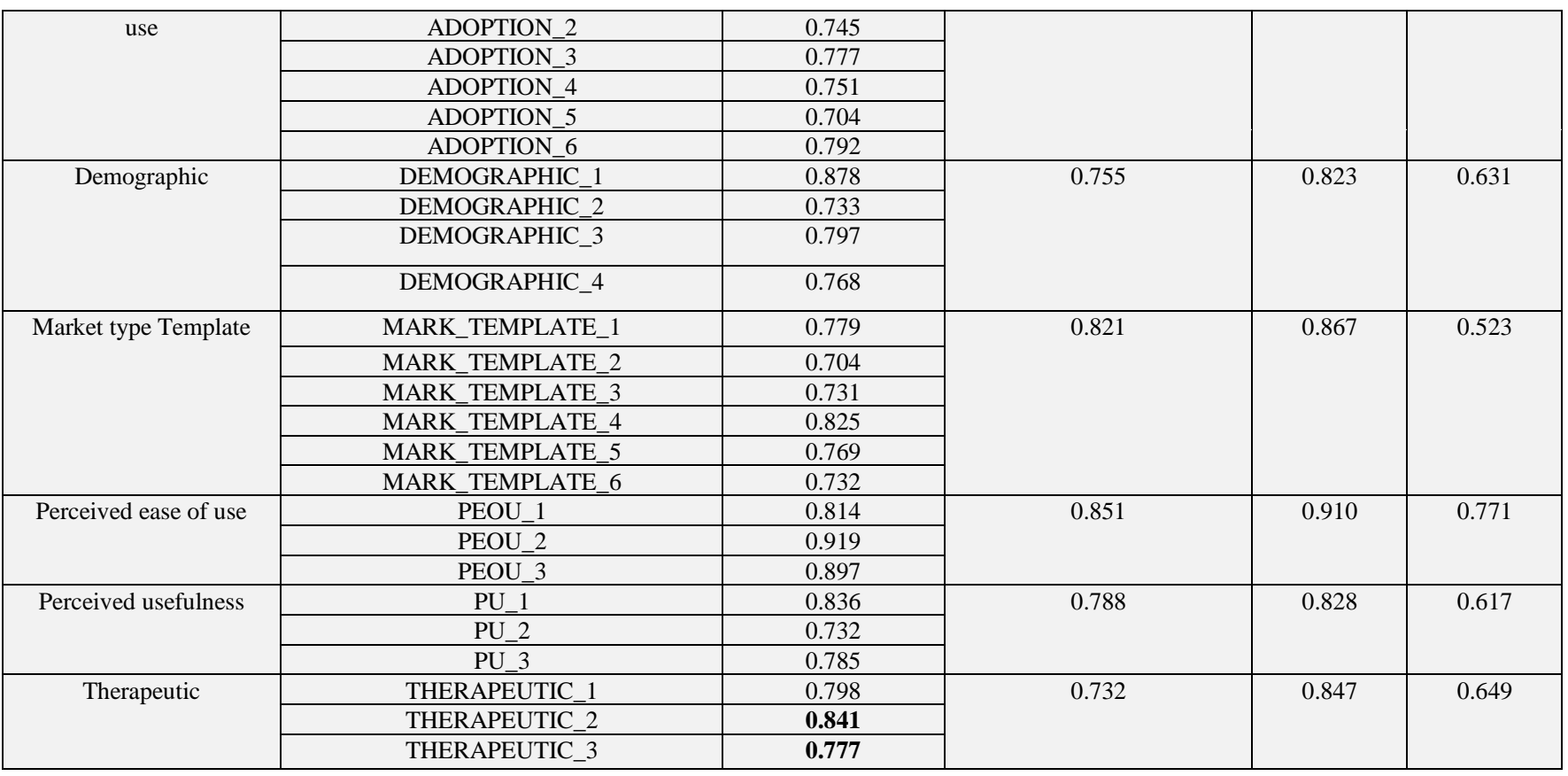

Table 2 reveals that the scale of Cronbach's Alpha values are from 0.732 (for Therapeutic) to 0.851 (for Perceived ease of use). According to [43], [44], the lowest value of 0.7 has been fulfilled in all respects. In addition, the individual item reliability has been evaluated and the factor loadings of all variables have been examined with their particular constructs. As per the findings, it was observed that all variables vary between 0.704 and 0.919 (for ADOPTION_5 and for PEOU_2 respectively), which have fulfilled with the value of 0.7 , the least value [45]. Regarding final measurement of our model's reliability, the composite reliability has been carefully checked. The requirement of 0.7 was fulfilled by all constructs as per the results [45]. Therefore, the reliability of our research model was found good enough. The convergent validity is another measurement that needs to be considered, which describes the extent to measure the same concept [46]. In this research study, values of average variance extracted (AVE) can be tested to measure the convergent validity. As depicted in Table 2, above 0.5 was reportedly the AVE for all constructs, which satisfied the criteria [45]. A good convergent validity for the scales is thus revealed. Concerning the final measurement of our research model, the discriminant validity was also evaluated. The variance shared between the construct and other constructs can be measured to achieve this [46]. Table 2 demonstrates the computation results.

\begin{tabular}{|l|r|c|c|c|c|c|}
\hline & $\begin{array}{c}\text { Market } \\
\text { type } \\
\text { Template }\end{array}$ & Demographic & $\begin{array}{c}\text { Behavior } \\
\text { Intention } \\
\text { to use }\end{array}$ & $\begin{array}{c}\text { Perceive } \\
\text { d ease of } \\
\text { use }\end{array}$ & $\begin{array}{c}\text { Perceired } \\
\text { usefulness }\end{array}$ & Therapeutic \\
\hline $\begin{array}{l}\text { Market type } \\
\text { Template }\end{array}$ & 0.697 & & & & & \\
\hline Demographic & 0.651 & 0.798 & & & & \\
\hline $\begin{array}{l}\text { Behavior } \\
\text { Intention to } \\
\text { use }\end{array}$ & 0.717 & 0.633 & 0.723 & & & \\
\hline $\begin{array}{l}\text { Perceived } \\
\text { ease of use }\end{array}$ & 0.690 & 0.632 & 0.635 & 0.878 & & \\
\hline $\begin{array}{l}\text { Perceived } \\
\text { usefulness }\end{array}$ & 0.637 & 0.504 & 0.569 & 0.598 & 0.786 & \\
\hline Therapeutic & 0.530 & 0.522 & 0.606 & 0.677 & 0.688 & 0.806 \\
\hline
\end{tabular}

Table 3 shows that the AVE and all of their square roots were greater than their equivalent coefficients of correlation along with other factors. This is suggestive of the fact that the discriminant validity test is met by all the constructs. By evaluating these results, both the convergent and discriminant validity have been fulfilled by our investigations.

\subsection{Hypotheses Testing - Path Coefficient}

The evaluation of the structural model is believed to be the second step in investigating the PLS method. In line with the standardized paths, analysis of hypotheses and constructs' relationship is provided by this model. Figure 2 and Table 4 both exhibit the findings of our assessment. This research model explains $33.2 \%$ in perceived usefulness, $43.9 \%$ of variations in perceived ease of use and $29.9 \%$ in behavior intention to use. All the previously defined hypotheses were also tested and this was done by performing a path analysis. In particular, the data supported eight out of nine hypotheses.

Three endogenous variables were verified in the model (PU, PEOU, and BI). Based on the data analysis, hypotheses H1, H2, $\mathrm{H} 3, \mathrm{H} 4, \mathrm{H} 5, \mathrm{H} 6, \mathrm{H} 8$, and $\mathrm{H} 9$ were supported by the empirical data, while $\mathrm{H} 7$ was rejected. The results revealed that 'Perceived ease of use' (PEOU) significantly influenced 'Behavior intention to use' $(\mathrm{BI})(\beta=0.459, \mathrm{P}<0.001)$ supporting hypothesis $\mathrm{H} 8$, while $\mathrm{H} 7$ was rejected. The results showed that 'Perceived ease of use' (PEOU) not significantly influenced 'Perceived usefulness' (PU) ( $\beta=0.019, \mathrm{P}=0.914)$. Hence, $\mathrm{H} 7$ is not supported. 'Perceived usefulness' (PEOU) was determined to be significant in affecting 'Behavior intention to use' (BI) $(\beta=0.295, \mathrm{P}<0.01)$, supporting hypotheses H9. Market type Template $(\beta=0.370, \mathrm{P}<$ $0.01)$, Therapeutic $(\beta=0.479, \mathrm{P}<0.001)$, Demographic $(\beta=$ $0.389, \mathrm{P}<0.01)$ have positive significant effect on 'Perceived usefulness' (PU). As the result, hypotheses H1, H3, and $\mathrm{H} 5$ are supported. The relationship between 'Perceived ease of use' (PEOU) and 'Market type Template' $(\beta=0.460, \mathrm{P}<0.001)$, 'Therapeutic' $(\beta=0.433, \mathrm{P}<0.001)$, and 'Demographic' $(\beta=$ $0.498, \mathrm{P}<0.001$ are statistically significant, and hypotheses $\mathrm{H} 2$, $\mathrm{H} 4$, and $\mathrm{H} 6$ are generally supported. A summary of the hypotheses testing results is shown in Table 4.

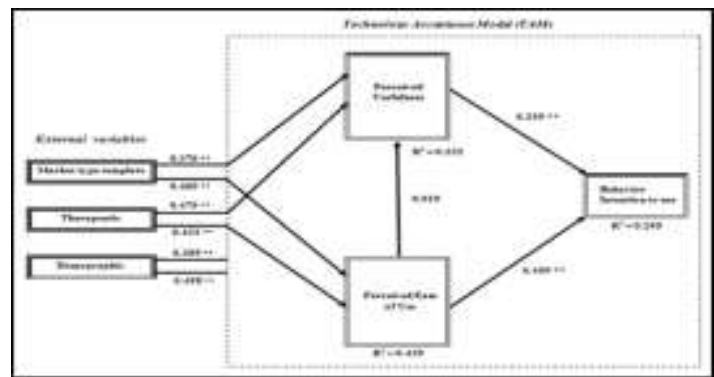

Fig. 4: Summary of Hypothesis Results 
Table 4: Results of structural model (significant at $\mathrm{p}^{* *}<=0.01, \mathrm{p}^{*}<0.05$ )

\begin{tabular}{|c|c|c|c|c|c|c|}
\hline $\mathrm{H}$ & Relationship & Path & $t$-Value & $p$-Value & Direction & Decision \\
\hline H1 & $\begin{array}{c}\text { Market type Template -> } \\
\text { Perceived usefulness }\end{array}$ & 0.370 & 3.255 & 0.001 & Positive & $\begin{array}{c}\text { Supported } \\
* * \\
\end{array}$ \\
\hline $\mathrm{H} 2$ & $\begin{array}{c}\text { Market type Template -> } \\
\text { Perceived ease of use }\end{array}$ & 0.460 & 6.124 & 0.000 & Positive & Supported** \\
\hline $\mathrm{H} 3$ & $\begin{array}{c}\text { Therapeutic -> Perceived } \\
\text { usefulness }\end{array}$ & 0.479 & 4.712 & 0.000 & Positive & Supported $* *$ \\
\hline $\mathrm{H} 4$ & $\begin{array}{c}\text { Therapeutic }->\text { Perceived } \\
\text { ease of use }\end{array}$ & 0.433 & 4.862 & 0.000 & Positive & Supported $* *$ \\
\hline H5 & $\begin{array}{c}\text { Demographic }->\text { Perceived } \\
\text { usefulness }\end{array}$ & 0.389 & 4.663 & 0.002 & Positive & Supported** \\
\hline H6 & $\begin{array}{c}\text { Demographic }->\text { Perceived } \\
\text { ease of use }\end{array}$ & 0.498 & 5.223 & 0.000 & Positive & Supported $* *$ \\
\hline $\mathrm{H} 7$ & $\begin{array}{l}\text { Perceived ease of use }-> \\
\text { Perceived usefulness }\end{array}$ & 0.019 & 0.108 & 0.914 & Positive & Not supported \\
\hline H9 & $\begin{array}{l}\text { Perceived usefulness }-> \\
\text { Behavior Intention to use }\end{array}$ & 0.295 & 2.771 & 0.006 & Positive & Supported** \\
\hline
\end{tabular}

\section{Conclusion}

The research study indicates that the market type template, therapeutic would help enhance the tourists' perceived ease of use of smartphone usage. It has also been observed that a positive influence was subjected upon the market type template including the perceived ease of use and perceived usefulness and supported $\mathrm{H} 1$ and $\mathrm{H} 2$. Positive influence was also subjected upon the therapeutic on perceived ease of use and perceived usefulness, supporting the $\mathrm{H} 3$ and $\mathrm{H} 4$. With the help of this outcome, it is possible to indicate the tourist significance in terms of competency and high confidence levels when making use of smartphone applications. The market type template on perceived ease of use subjects a positive influence and has been observed in earlier research studies). Market type template and therapeutic predicted perceived ease of use are variables which indicate a variance of $44 \%\left(R^{2}=0.439\right)$ upon the perceived ease of use. This shows that the moderate predictive power R-squared value upon the entire scenario. Market type template and therapeutic predicted perceived usefulness together are variables which indicate a variance of explained $33 \%\left(\mathbb{R}^{2}=0.332\right)$ within the 'perceived usefulness', and this shows the moderate overall R-squared value. 'Perceived ease of use' indicates a variance of $30 \%$ within 'behavioural intention' $\left(R^{2}=0.299\right)$, indicating that a weak overall $\mathrm{R}$-squared value is present. Hence, the main aspects of the research are that there is a positive influence of the market type template and therapeutic on tourists' perceived ease of use and perceived usefulness of smartphone applications. It is necessary for the tourism smartphone applications' lawmakers and managers to consider the factors which significantly influence the enhancement of tourism and increase the efficiency of tourists when designing and implementing procedures to attain effective smartphone applications.

\section{Acknowledgment}

The author would like to thank the Research Management, Innovation and Commercialization Centre, Universiti Sultan Zainal Abidin, Terengganu, Malaysia for providing the financial assistance to support the publication fee of this article.

\section{References}

[1] Barnes, S. J., \& Scornavacca, E. (2004). Mobile marketing: The role of permission and acceptance. International Journal of Mobile Communications, 2(2), 128-139.
[2] Wilson, A., Zeithaml, V. A., Bitner, M. J., \& Gremler, D. D. (2012). Services marketing: Integrating customer focus across the firm. McGraw Hill.

[3] Salem, F. (2017). Social media and the internet of things towards data-driven policymaking in the Arab World: Potential, limits and concerns.

https://poseidon01.ssrn.com/delivery.php?ID=08911910506400511 409602310207009212402204603902104205506408611509609807 611711109602806303300000810901602609312703010302512109 300604106204603601508602911311712412200500902806610008 711301601211507210911202309002109900312209812303002802 $5077108080069123 \&$ EXT $=$ pdf.

[4] Wu, J. H., \& Wang, S. C. (2005). What drives mobile commerce?: An empirical evaluation of the revised technology acceptance model. Information and Management, 42(5), 719-729.

[5] Minazzi, R. (2015). Social media marketing in tourism and hospitality. Springer.

[6] Persaud, A., \& Azhar, I. (2012). Innovative mobile marketing via smartphones: Are consumers ready? Marketing Intelligence and Planning, 30(4), 418-443.

[7] Magatef, S. G. (2015). The impact of tourism marketing mix elements on the satisfaction of inbound tourists to Jordan. International Journal of Business and Social Science, 6(7), 41-58.

[8] Connell, J. (2006). Medical tourism: Sea, sun, sand and... surgery. Tourism Management, 27(6), 1093-1100.

[9] Helble, M. (2011). The movement of patients across borders: Challenges and opportunities for public health. Bulletin of the World Health Organization, 89, 68-72.

[10] Bazazo, I. K., \& Alananzeh, O. A. (2016). The effect of electronic tourism in enabling the disabled tourists to communicate with the touristic and archaeological sites case study-Jordan. European Scientific Journal, 12(5). 111-128.

[11] Matceyevsky, D., Hahoshen, N. Y., Asna, N., Khafif, A., \& BenYosef, R. (2007). Assessing the effectiveness of Dead Sea products as prophylactic agents for acute radiochemotherapy-induced skin and mucosal toxicity in patients with head and neck cancers: A phase 2 study. Chemotherapy, 9(12), 439-442.

[12] Kangas, B. (2002). Therapeutic itineraries in a global world: Yemenis and their search for biomedical treatment abroad. Medical Anthropology, 21(1), 35-78.

[13] Hanley, M., \& Becker, M. (2008). Cell phone usage and advertising acceptance among college students: A four-year analysis. International Journal of Mobile Marketing, 3(1), 67-80.

[14] Komulainen, H., Mainela, T., Tähtinen, J., \& Ulkuniemi, P. (2007). Retailers' different value perceptions of mobile advertising service. International Journal of Service Industry Management, 18(4), 368-393.

[15] Ström, R., Vendel, M., \& Bredican, J. (2014). Mobile marketing: A literature review on its value for consumers and retailers. Journal of Retailing and Consumer Services, 21(6), 1001-1012.

[16] Sutanto, J., Palme, E., Tan, C. H., \& Phang, C. W. (2013). Addressing the personalization-privacy paradox: An empirical assessment from a field experiment on smartphone users. MIS 
Quarterly, 37(4), 1141-1164.

[17] Wang, D., Park, S., \& Fesenmaier, D. R. (2012). The role of smartphones in mediating the touristic experience. Journal of Travel Research, 51(4), 371-387.

[18] Yuan, S. T., \& Tsao, Y. W. (2003). A recommendation mechanism for contextualized mobile advertising. Expert Systems with Applications, 24(4), 399-414.

[19] Shan, L. H., Chin, T. A., Sulaiman, Z., \& Muharam, F. M. (2016) Effective mobile advertising on mobile devices. Journal of Global Business and Social Entrepreneurship, 2(4), 164-177.

[20] Chen, P. T., Cheng, J. Z., Yu, Y. W., \& Ju, P. H. (2014). Mobile advertising setting analysis and its strategic implications. Technology in Society, 39, 129-141.

[21] Erawan, T. (2016). Tourists' intention to give permission via mobile technology in Thailand. Journal of Hospitality and Tourism Technology, 7(4), 330-346.

[22] Mattimoe, R., \& Seal, W. (2011). Pricing in a service sector context: Accounting and marketing logics in the hotel industry. European Accounting Review, 20(2), 355-388.

[23] Al-Azzam, A. F. M. (2016). A study of the impact of marketing mix for attracting medical tourism in Jordan. International Journal of Marketing Studies, 8(1), 139-149.

[24] Wafik, G. M. (2015). The role of tourism marketing in achieving competitive advantage for Egypt as a therapeutic destination. $\mathrm{PhD}$ thesis, Fayoum University.

[25] Bookman, M. (2007). Medical tourism in developing countries Springer.

[26] Penni, J. (2015). The online evolution of social media: An extensive exploration of a technological phenomenomen and its extended use in various activities. PhD thesis, University of Huddersfield.

[27] Davis, F. D. (1989). Perceived usefulness, perceived ease of use, and user acceptance of information technology. MIS Quarterly, 13(3), 319-340.

[28] Taylor, S., \& Todd, P. A. (1995). Understanding information technology usage: A test of competing models. Information Systems Research, 6(2), 144-176.

[29] Chen, J., Park, Y., \& Putzer, G. J. (2010). An examination of the components that increase acceptance of smartphones among healthcare professionals. Electronic Journal of Health Informatics, $5(2), 1-12$

[30] Venkatesh, V. (2000). Determinants of perceived ease of use: Integrating control, intrinsic motivation, and emotion into the technology acceptance model. Information Systems Research, 11(4), 342-365.

[31] Shin, D. H., Shin, Y. J., Choo, H., \& Beom, K. (2011) Smartphones as smart pedagogical tools: Implications for smartphones as u-learning devices. Computers in Human Behavior, 27(6), 2207-2214.

[32] Verkasalo, H., López-Nicolás, C., Molina-Castillo, F. J., \& Bouwman, H. (2010). Analysis of users and non-users of smartphone applications. Telemat. Informatics, 27(3), 242-255.

[33] Sanakulov, N., \& Karjaluoto, H. (2017). A cultural comparison study of smartphone adoption in Uzbekistan, South Korea and Turkey. International Journal of Mobile Communications, 15(1), 85-103.

[34] Wang, D., Xiang, Z., \& Fesenmaier, D. R. (2014). Adapting to the mobile world: A model of smartphone use. Annals of Tourism Research, 48, 11-26.

[35] Tan, G. W. H., Lee, V. H., Lin, B., \& Ooi, K. B. (2017). Mobile applications in tourism: The future of the tourism industry? Industrial Management and Data Systems, 117(3), 560581.

[36] Sachdev, S. B., \& Verma, H. V. (2004). Relative importance of service quality dimensions: A multisectoral study. Journal of Services Research, 4(1), 93-116.

[37] Hair Jr, J. F., Hult, G. T. M., Ringle, C., \& Sarstedt, M. (2016). A primer on partial least squares structural equation modeling (PLSSEM). Sage Publications.

[38] Wang, M. H., \& Yang, T. Y. (2016). Investigating the success of knowledge management: An empirical study of small-and mediumsized enterprises. Asia Pacific Management Review, 21(2), 79-91.

[39] Chin, W. W., \& Newsted, P. R. (1999). Structural equation modeling analysis with small samples using partial least squares. Statistical Strategies for Small Sample Research, 1(1) $307-341$

[40] Anderson, J. C., \& Gerbing, D. W. (1988). Structural equation modeling in practice: A review and recommended two-step approach. Psychological Bulletin, 103(3), 411-423.

[41] Riskinanto, A., Kelana, B., \& Hilmawan, D. R. (2017). The moderation effect of age on adopting e-payment technology. Procedia Computer Science, 124, 536-543.

[42] Hair, J. F., Black, W. C., Babin, B. J., Anderson, R. E., \& Tatham, R. L. (2006). Multivariate data analysis. Prentice Hall.

[43] Gefen, D., Straub, D., \& Boudreau, M. C. (2000). Structural equation modeling and regression: Guidelines for research practice. Communications of the Association for Information Systems, 4(1), 1-77.

[44] Nunnally, J. C., \& Bernstein, I. H. (1967). Psychometric theory. McGraw-Hill.

[45] Chin, W. W. (1998). The partial least squares approach to structural equation modeling. Modern Methods for Business Research, 295(2), 295-336.

[46] Fornell, C., \& Larcker, D. F. (1981). Evaluating structural equation models with unobservable variables and measurement error. Journal of Marketing Research, 18(1), 39-50. 